\title{
Long-term tillage and nitrogen management for improving productivity and profitability of a rainfed maize-wheat system in north western Himalaya
}

\begin{tabular}{lll}
\hline Paper received: 26.07 .2017 & Revised received: 20.02.2018 & Re-revised received: 15.07 .2018 \\
\hline
\end{tabular}

\section{Authors Info \\ S. Singh ${ }^{1 *}$, S.S. Bawa ${ }^{2}$, S. Singh ${ }^{2}$, S.C. Sharma ${ }^{2}$, P. Sheoran ${ }^{3}$, V. Sardana ${ }^{4}$ and A. Salaria ${ }^{4}$ \\ ${ }^{1}$ Crop Production Division, ICAR-Vivekananda Parvatiya Krishi Anusandhan Sansthan, Almora-263 601, India \\ ${ }^{2}$ Regional Research Station for Kandi Area, Punjab Agricultural University, \\ Ballowal Saunkhri-144 521, India \\ ${ }^{3}$ Division of Technology Evaluation and Transfer, ICAR-Central Soil Salinity Research Institute, Karnal-132 001, India \\ ${ }^{4}$ Department of Agronomy, Punjab Agricultural University, Ludhiana-141 004, India \\ *Corresponding Author Email : sher.singh@icar.gov.in}

\section{Edited by \\ Dr. Avtar Singh}

Reviewed by Dr. Sunanda Biswas Dr. V. Paramesha

\section{Abstract}

Aim: The study aimed to identify the optimum tillage and source of nitrogen for refining yields, yield sustainability and rainwater-use efficiency, and to develop predictive models explaining the relationship between crop yield and monthly rainfall with main goal of reduced cost of cultivation and increased profitability for long-term sustainability of maize-wheat system.

Methodology: A long-term field experiment on maize-wheat system was conducted from 2000 to 2012 at Regional Research Station, Ballowal Saunkhri, Punjab Agricultural University, Ludhiana in split plot design with three replications. The treatment included three tillage practices, viz., conventional tillage (CT), reduced tillage $\left(R T_{1}\right)$ and $R T_{1}$ + herbicide $\left(R T_{2}\right)$ in the main plots and three nitrogen $(\mathrm{N})$ management practices, viz., $100 \% \mathrm{~N}$ from organic source $\left(\mathrm{F}_{1}\right), 50 \% \mathrm{~N}$ from organic $+50 \% \mathrm{~N}$ from inorganic source $\left(F_{2}\right)$ and $100 \% \mathrm{~N}$ from inorganic source $\left(\mathrm{F}_{3}\right)$ in the sub-plots. The parameters included maize and wheat yield, rainwater use efficiency, economics, sustainability yield index to develop predictive models.

Results: Prediction models expressing relation between yield and monthly rainfall showed beneficial effect of rainfall in June, July and September months on maize and January and February in wheat on crop productivity. $\mathrm{RT}_{2}$ gave highest mean maize grain yield $\left(2264 \mathrm{~kg} \mathrm{ha}^{-1}\right)$ with 13.8 and $1.8 \%$ yield superiority over $\mathrm{RT}_{1}$ and CT, respectively. However, in wheat, CT recorded highest grain yield $\left(2110 \mathrm{~kg} \mathrm{ha}^{-1}\right)$ with 7.9 and $1.7 \%$ higher yield than $R T_{1}$ and $R T_{2}$, respectively. The $R T_{2} F_{3}$ gave highest net returns of US $\$ 222.60$ ha $^{-1}$ with benefit-cost ratio (B:C) of 1.88, rain water use efficiency (RWUE) of $4.78 \mathrm{~kg} \mathrm{ha}^{-1} \mathrm{~mm}^{-1}$ and a sustainable yield index (SYI) of $60.7 \%$ in maize, whereas in wheat it provided net returns of US $\$ 315.45 \mathrm{ha}^{-1}$ with B:C of 2.28 , RWUE of $23.0 \mathrm{~kg} \mathrm{ha}^{-1} \mathrm{~mm}^{-1}$ and SYI of $47.4 \%$.

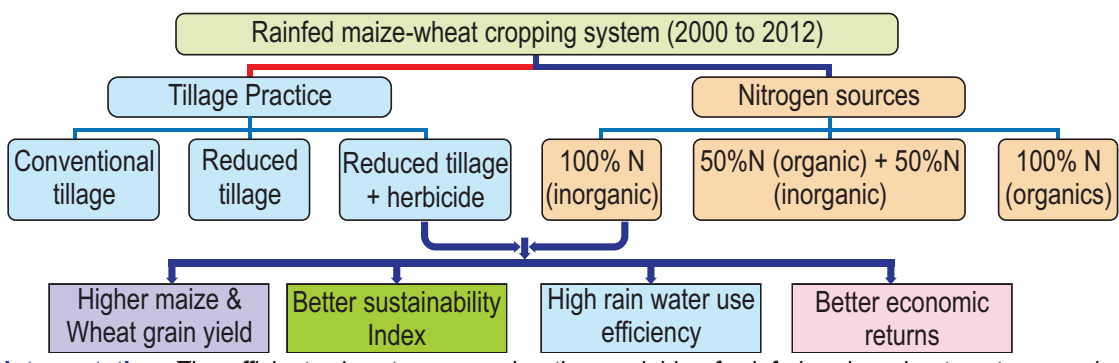

Interpretation: The efficient rainwater use and optimum yields of rainfed maize-wheat system can be realised with reduced tillage + herbicide based weed management along with application of recommended nitrogen. The study suggests the shift from conventional tillage practices to reduced/conservation tillage practices.

Keywords : Economics, Nitrogen sources, Prediction model, Reduced tillage, Sustainability

How to cite : Singh, S., S.S. Bawa, S. Singh, S.C. Sharma, P. Sheoran, V. Sardana and A. Salaria: Long-term tillage and nitrogen management for improving productivity and profitability of a rainfed maize-wheat system in the north western Himalaya. J. Environ. Biol., 40, 36-44 (2019). 


\section{Introduction}

Rainfed agriculture covers about $60 \%$ of the net sown area and supports 40\% Indians (Maruthi Sankar et al., 2012). Apart from the climatic constraints like erratic and unreliable spatio-temporal rainfall patterns, the soils are highly degraded in the rainfed areas (Sharma et al., 2005; Maruthi Sankar et al., 2010), which results in low productivity and profitability of crops (Sharma et al., 2011). While conventional tillage and higher use of chemical fertilisers and pesticides increased crop yields and enhanced food security, at the same time these management practices have adversely affected soil quality in terms of decreased soil organic carbon, shrinking biodiversity and loss of surface crop residue, as well as productivity (Cruse and Colvin, 1989; Sundermeier et al., 2011). Reduced tillage helps in reducing erosion losses, conserving soil moisture and obtaining yields similar to that with conventional tillage (Bhatt et al., 2004).

The imbalanced use of fertilizers and meagre crop residues recycling has further intensified the problem of deteriorated soil quality leading to low crop productivity in rainfed regions (Sharma et al., 2008). Small holder agriculture in the lower Shivalik foothill region is characterised by mouldboard ploughing and hand hoeing, which leads to land degradation and loss of excessive nutrient (Singh et al., 2015). Primary tillage along with application of organic residues and nitrogen is essential to maintain high crop yield, as well as soil quality (Sharma et al., 2005). Reduced or conservation tillage offer ecological, economic and organisational benefits (Hussain et al., 1999). It has been reported that elimination of summer fallowing and adopting conservation tillage with residue mulching in arid and semi-arid regions improve soil structure, increases infiltration capacity, lowers bulk density (Shaver et al., 2002; Lal, 2004) and ultimately enhances crop productivity. Thus, optimal tillage practices combined with fertiliser and weed management would be crucial, not only to increase crop productivity but also to retain soil health and sustainability (Nema et al., 2008; Maruthi Sankar et al., 2012).

The regression models for predicting the treatment effect on grain yield using monthly rainfall events of the actual growing season could be of interest to predict the final crop yield with the likely fluctuation. Similar regression models have also been successfully developed and used earlier by Sharma et al. (2009), Maruthi Sankar et al. (2010) and Maruthi Sankar et al. (2012) for soybean, pearlmillet and many other crops under semi-arid conditions of India.

Maize (Zea mays L.) - wheat (Triticum aestivum L.) rotation is the third most important cropping system in India and is grown on about 1.13 million ha. Rainfed maize-wheat is the major cropping system in foothill regions of India (Singh et al., 2011). This region is suffering from number of biophysical and socioeconomic problems and needs urgent attention to curtail cost of cultivation and increase profitability for sustainability of maizewheat system by developing and adopting appropriate tillage and nutrient management strategies. In view of the above, the present study focused on the assessment of long-term effects of tillage and use of nitrogen from various sources on productivity and profitability of a rainfed maize-wheat system.

\section{Materials and Methods}

Experimental site : A long-term (2000-2012) field experiment was conducted at Punjab Agricultural University Regional Research Station, Ballowal Saunkhri, India to study the effect of tillage and nitrogen management through various sources on the productivity of maize-wheat rotation. The experimental site represents the lower Shivalik foothills of Indian Punjab and experiences sub-humid climate with dry and hot summer and extremely cold winter. The average annual rainfall of the region is around $1129 \mathrm{~mm}$ and about $80 \%$ of rainfall is received during a short span of July to mid September with very scanty rainfall during winter and spring seasons.

Experimental design, treatments, agronomic practices and soil characteristics : The field experiment was conducted with maize (kharif) and wheat (rabi) crops in a sequence using spiltplot design. The experiment (Table 1) consisted of three tillage practices: conventional tillage $(C T)$, reduced tillage $\left(R T_{1}\right)$ and reduced tillage + herbicide $\left(\mathrm{RT}_{2}\right)$ in the main plot and three nitrogen (N) management practices: $100 \% \mathrm{~N}$ from organic source $\left(F_{1}\right), 50 \% N$ from organic source $+50 \% N$ from inorganic source $\left(F_{2}\right)$ and $100 \% \mathrm{~N}$ from inorganic source $\left(F_{3}\right)$ in sub-plots.

The experimental soil was loamy, low in organic carbon $(0.24 \%)$, very low in available $\mathrm{N}\left(98.3 \mathrm{~kg} \mathrm{ha}^{-1}\right)$ and $\mathrm{P}\left(16.4 \mathrm{~kg} \mathrm{ha}^{-1}\right)$, and medium in $\mathrm{K}\left(189.3 \mathrm{~kg} \mathrm{ha}^{-1}\right)$. Soil moisture retention at permanent wilting point ( 15 bar) was 3.1 while field capacity ( $1 / 3$ bar) was 10.4 with $24.8 \mathrm{~cm} / 1.8 \mathrm{~m}$ of available water. The bulk density of soil was $1.38 \mathrm{Mg} \mathrm{m}^{-3}$ with $\mathrm{pH} 8.1$ and electrical conductivity of $0.21 \mathrm{dS} \mathrm{m}^{-1}$.

Sowing, harvesting and rainfall details : The sowing time of maize was influenced by the onset of monsoon rains during the study period. The onset of monsoon rains along with its withdrawal influenced crop duration and harvesting of maize crop, as well as sowing time of the succeeding wheat crop (Table 2). The monthly rainfall (June to March) and the crop season rainfall (CRF) for maize and wheat during 2000 to 2012 were considered independently for assessing the treatment effect. A rainfall event of $\geq 2.5 \mathrm{~mm}$ day $^{-1}$ was considered for calculating the cumulative rainfall of a month. Total CRF over the study period for maize crop ranged from 388 to $870 \mathrm{~mm}$ with a mean of $552 \mathrm{~mm}$ and CV of $25.9 \%$ (Table 2).

Statistical analysis : The ANOVA of the experiment was performed in split plot design using SPSS version 16 (SPSS, 
Table 1 : Details of treatments and agronomic practices followed

\begin{tabular}{|c|c|c|}
\hline Treatments & Maize (July-October) & Wheat (October-April) \\
\hline \multicolumn{3}{|l|}{ Tillage practices } \\
\hline Conventional tillage (CT) & $\begin{array}{l}4 \text { ploughings ( } 1 \text { summer ploughing }+2 \text { disk } \\
\text { harrowing }+1 \text { cultivator ploughing followed } \\
\text { by planking) + } 1 \text { interculture at } 25 \text { days after } \\
\text { sowing (DAS) }\end{array}$ & $\begin{array}{l}4 \text { ploughings ( } 2 \text { disk harrowing followed by planking+ } \\
2 \text { cultivator ploughings followed by } 1 \text { planking)+ } \\
1 \text { interculture at } 25 \text { DAS }\end{array}$ \\
\hline Reduced tillage $\left(\mathrm{RT}_{1}\right)$ & $\begin{array}{l}2 \text { ploughings ( } 1 \text { disk harrowing }+1 \text { cultivator } \\
\text { ploughing followed by planking) }+1 \text { interculture } \\
\text { at } 25 \text { DAS }\end{array}$ & $\begin{array}{l}2 \text { ploughings ( } 1 \text { disk harrowing followed by planking+ } \\
1 \text { cultivator ploughing followed by planking)+ } \\
1 \text { interculture at } 25 \text { DAS }\end{array}$ \\
\hline Reduced tillage + herbicide $\left(\mathrm{RT}_{2}\right)$ & $\begin{array}{l}\mathrm{RT}_{1}+\text { pre-emergence herbicide spray } \\
\left(\text { Atrazine @ } 1.0 \mathrm{~kg} \text { a.i. ha }{ }^{-1}\right)\end{array}$ & $\begin{array}{l}\mathrm{RT}_{1}+\text { post-emergence herbicide spray } \\
\text { (Isoproturon @ 0.94 kg a.i. ha' }{ }^{-1} \text { ) }\end{array}$ \\
\hline \multicolumn{3}{|l|}{ Nitrogen application } \\
\hline $100 \% \mathrm{~N}$ from organic source $\left(F_{1}\right)$ & $80 \mathrm{~kg} \mathrm{~N} \mathrm{ha}^{-1}$ through compost (organic) ${ }^{\dagger}$ & $80 \mathrm{~kg} \mathrm{~N} \mathrm{ha}^{-1}$ through compost (organic) ${ }^{\dagger}$ \\
\hline $50 \% \mathrm{~N}$ from organic source $+50 \%$ & $40 \mathrm{~kg} \mathrm{~N} \mathrm{ha}^{-1}$ through compost (organic) ${ }^{\dagger}+$ & $40 \mathrm{~kg} \mathrm{~N} \mathrm{ha}^{-1}$ through compost (organic) ${ }^{+}+$ \\
\hline $\mathrm{N}$ from inorganic source $\left(\mathrm{F}_{2}\right)$ & $40 \mathrm{~kg} \mathrm{~N} \mathrm{ha}^{-1}$ through urea (inorganic) ${ }^{\ddagger}$ & $40 \mathrm{~kg} \mathrm{~N} \mathrm{ha}^{-1}$ through urea (inorganic) ${ }^{\ddagger}$ \\
\hline $\begin{array}{l}100 \% \mathrm{~N} \text { from inorganic } \\
\text { source }\left(\mathrm{F}_{3}\right)\end{array}$ & $80 \mathrm{~kg} \mathrm{~N} \mathrm{ha}^{-1}$ through urea (inorganic) ${ }^{\ddagger}$ & $80 \mathrm{~kg} \mathrm{~N} \mathrm{ha}^{-1}$ through urea (inorganic) ${ }^{\ddagger}$ \\
\hline Hybrid/Variety & JH3459* (hybrid) & PBW 175 (variety) \\
\hline Seed rate $\left(\mathrm{kg} \mathrm{ha}^{-1}\right)$ & 20 & 100 \\
\hline \multicolumn{3}{|l|}{ Spacing } \\
\hline -Row-row (cm) & 45.0 & 30 \\
\hline - Plant-plant (cm) & 22.5 & Approx 2.0 \\
\hline $\begin{array}{l}\text { Fertilisation (applied at } \\
\text { sowing time) }\end{array}$ & $\begin{array}{l}40 \mathrm{~kg} \mathrm{ha}^{-1} \mathrm{P}_{2} \mathrm{O}_{5} \text { through single super phosphate } \\
(\mathrm{SSP})+20 \mathrm{~kg}^{-1} \mathrm{~K}_{2} \mathrm{O} \text { through murate of } \\
\text { potash (MOP) }\end{array}$ & $\begin{array}{l}40 \mathrm{~kg} \mathrm{ha}^{-1} \mathrm{P}_{2} \mathrm{O}_{5} \text { through SSP }+20 \mathrm{~kg} \mathrm{ha}^{-1} \mathrm{~K}_{2} \mathrm{O} \\
\text { through MOP }\end{array}$ \\
\hline
\end{tabular}

${ }^{\dagger}$ Compost (1.38 to $1.63 \% \mathrm{~N}, 1.41$ to $1.59 \% \mathrm{P}_{2} \mathrm{O}_{5}$ and 1.50 to $1.95 \% \mathrm{~K}$ O) was applied about $3-4$ weeks before sowing in both crops. Compost consisted of farm yard manure, green leaves of Leucaena leucocephala and wheat straw. ${ }^{\ddagger}$ Half of the prescribed dose of urea $(46 \% \mathrm{~N})$ to each crop was applied at the time of sowing and the remaining half was top dressed at knee height stage in maize and after winter rains in wheat *Single cross hybrid 'Parkash' was grown during kharif2009

2007), and the differences among tillage and nitrogen treatments were compared by LSD at significance level of $p<0.05$ (Gomez and Gomez, 1984).

Treatment-specific linear regression models were developed using grain yields and total monthly rainfall (RF) received for assessing the rainfall effect on crop yields (Draper and Smith, 1998). The expression of linear regression model for both maize and wheat are given as:

Maize : Y $- \pm \alpha \pm \beta_{1}\left(\right.$ Jun RF) $\pm \beta_{2}\left(\right.$ Jul RF) $\pm \beta_{3}($ Aug RF $) \pm \beta_{4}($ Sep $\mathrm{RF}$ )

Wheat: $Y- \pm \alpha \pm \beta_{1}(\mathrm{Oct} R F) \pm \beta_{2}(\operatorname{Nov} R F) \pm \beta_{3}(\mathrm{Dec} R F) \pm \beta_{4}($ Jan $\mathrm{RF}) \pm \beta_{5}(\mathrm{Feb} \mathrm{RF}) \pm \beta_{6}(\mathrm{Mar} \mathrm{RF})$

where, $\alpha$ is intercept and $\beta$ s are the slopes or regression coefficients measuring the change in yield for a unit change in the rainfall.

In order to identify the optimum combination of tillage and nitrogen practices for each crop, sustainability yield indices (SYI) were computed (Nema et al., 2008; Maruthi Sankar et al., 2012).
An efficient tillage and nitrogen treatment could be identified based on SYI derived as 'SYI' of treatment 'k' given as:

$$
S Y I=\left(\left(Y_{k}-E_{k}\right) /\left(Y_{\max }\right)\right) \times 100
$$

Where, $Y_{k}$ is the mean yield of $k^{\text {th }}$ treatment, $E_{k}$ is the prediction error based on the regression model of $k^{\text {th }}$ treatment and $Y_{\text {max }}$ is the maximum yield of a treatment in any year.

The rainwater use efficiency (RWUE) $\left(\mathrm{kg} \mathrm{ha}^{-1} \mathrm{~mm}^{-1}\right)$ for each treatment was computed as a ratio of crop yield and crop seasonal rainfall. To compute the economics and profitability of tillage and nitrogen treatments over years, the gross monetary returns, net monetary returns and benefit-cost ratios were calculated (Nema et al., 2008).

\section{Results and Discussion}

Reduced tillage + herbicide $\left(\mathrm{RT}_{2}\right)$ recorded maximum grain yield of maize $\left(2264 \mathrm{~kg} \mathrm{ha}^{-1}\right)$ which was 13.8 and $1.8 \%$ higher than reduced tillage $\left(\mathrm{RT}_{1}\right)$ and $\mathrm{CT}$, respectively (Table 3). Among the nitrogen sources, application of $100 \% \mathrm{~N}$ from 
Table 2: Sowing and harvesting time, crop growth period and temporal distribution of rainfall during maize and wheat growing seasons (2000-01 to 2011-12)

\begin{tabular}{|c|c|c|c|c|c|c|c|c|c|c|}
\hline \multirow{2}{*}{ Year } & \multirow{2}{*}{$\begin{array}{l}\text { Sowing } \\
\text { date }\end{array}$} & \multirow{2}{*}{$\begin{array}{l}\text { Harvest } \\
\text { date }\end{array}$} & \multirow{2}{*}{$\begin{array}{l}\text { Crop growth } \\
\text { period (days) }\end{array}$} & \multicolumn{6}{|c|}{ Rainfall (mm) } & \multirow[b]{2}{*}{$\mathrm{CRF}^{*}$} \\
\hline & & & & $\sqrt{\text { un }}$ & Jul & Aug & Sep & & & \\
\hline \multicolumn{11}{|l|}{$\overline{\text { Maize }}$} \\
\hline 2000 & 07.07 .00 & 28.09 .00 & 84 & 146 & 486 & 312 & 102 & & & 870 \\
\hline 2001 & 06.07 .01 & 27.09 .01 & 84 & 77 & 318 & 285 & 46 & & & 618 \\
\hline 2002 & 04.07 .02 & 01.10 .02 & 90 & 111 & 66 & 212 & 298 & & & 574 \\
\hline 2003 & 03.07 .03 & 24.09 .03 & 84 & 108 & 296 & 146 & 67 & & & 508 \\
\hline 2004 & 10.07 .04 & 28.09 .04 & 81 & 42 & 179 & 354 & 9 & & & 497 \\
\hline 2005 & 07.07 .05 & 01.10 .05 & 87 & 52 & 241 & 159 & 115 & & & 408 \\
\hline 2006 & 15.07 .06 & 06.10 .06 & 84 & 23 & 167 & 306 & 80 & & & 497 \\
\hline 2007 & 19.07.07 & 07.10 .07 & 81 & 131 & 210 & 152 & 154 & & & 388 \\
\hline 2008 & 14.07 .08 & 10.10 .08 & 89 & 435 & 75 & 295 & 257 & & & 589 \\
\hline 2009 & 27.07 .09 & 16.10 .09 & 82 & 27 & 190 & 202 & 87 & & & 391 \\
\hline 2010 & 17.07 .10 & 11.10 .10 & 87 & 80 & 347 & 171 & 219 & & & 542 \\
\hline 2011 & 12.07 .11 & 04.10 .11 & 85 & 303 & 139 & 492 & 153 & & & 742 \\
\hline Mean & 12 July & 4 Oct & 85 & 128 & 226 & 257 & 132 & & & 552 \\
\hline \multirow[t]{2}{*}{ CV $(\%)$} & - & - & 3.4 & 95.8 & 53.1 & 40.2 & 66.2 & & & 25.9 \\
\hline & & & & Oct & Nov & Dec & Jan & Feb & Mar & $\mathrm{CRF}^{*}$ \\
\hline \multicolumn{11}{|l|}{ Wheat } \\
\hline $2000-01$ & 11.11 .00 & 11.04 .01 & 151 & 0 & 0 & 29 & 9 & 1 & 36 & 77 \\
\hline 2001-02 & 17.11 .01 & 10.04 .02 & 145 & 0 & 0 & 8 & 22 & 25 & 13 & 68 \\
\hline $2002-03$ & 08.11 .02 & 19.04 .03 & 163 & 31 & 0 & 2 & 31 & 49 & 21 & 113 \\
\hline 2003-04 & 15.11 .03 & 06.04 .04 & 144 & 0 & 8 & 7 & 118 & 7 & 0 & 139 \\
\hline 2004-05 & 05.11 .04 & 17.04 .05 & 163 & 229 & 1 & 20 & 47 & 74 & 37 & 179 \\
\hline 2005-06 & 07.11 .05 & 07.04 .06 & 152 & 0 & 0 & 0 & 30 & 0 & 67 & 96 \\
\hline 2006-07 & 24.11 .06 & 27.04 .07 & 155 & 6 & 5 & 14 & 1 & 113 & 106 & 282 \\
\hline 2007-08 & 08.11 .07 & 11.04 .08 & 156 & 0 & 4 & 13 & 21 & 7 & 0 & 73 \\
\hline 2008-09 & 03.11 .08 & 05.04 .09 & 153 & 41 & 1 & 1 & 18 & 16 & 16 & 51 \\
\hline $2009-10$ & 19.11.09 & 06.04 .10 & 139 & 11 & 14 & 0 & 7 & 19 & 3 & 29 \\
\hline $2010-11$ & 28.10 .10 & 07.04 .11 & 162 & 46 & 0 & 61 & 13 & 96 & 22 & 192 \\
\hline $2011-12$ & 09.11 .11 & 13.04 .12 & 157 & 0 & 0 & 30 & 48 & 12 & 5 & 105 \\
\hline Mean & $11 \mathrm{Nov}$ & $12 \mathrm{Apr}$ & 153 & 30 & 3 & 15 & 30 & 35 & 27 & 117 \\
\hline CV $(\%)$ & - & - & 5.0 & 214.4 & 160.3 & 115.5 & 103.0 & 111.8 & 115.9 & 60.9 \\
\hline
\end{tabular}

CRF: Crop season rainfall (mm); CV: Coefficient of variation (\%); ${ }^{*} \mathrm{CRF}$ is total rainfall received during sowing to harvesting of a crop and not total months

inorganic source $\left(\mathrm{F}_{3}\right)$ provided maximum mean grain yield of maize $\left(2364 \mathrm{~kg} \mathrm{ha}^{-1}\right)$ which was 18.9 and $8.81 \%$ higher than $100 \% \mathrm{~N}$ from organic source $\left(F_{1}\right)$ and $50 \% \mathrm{~N}$ from organic source $+50 \% \mathrm{~N}$ from inorganic source $\left(\mathrm{F}_{2}\right)$, respectively. The interaction effect of tillage and nitrogen management was significant and $\mathrm{RT}_{2}$ $+\mathrm{F}_{3}$ recorded highest mean grain yield of maize to the extent of $2493 \mathrm{~kg} \mathrm{ha}^{-1}$. The maximum mean grain yield of wheat $(2110 \mathrm{~kg}$ ha $^{-1}$ ) was observed with CT which was 7.9 and $1.7 \%$ higher than $\mathrm{RT}_{1}$ and $\mathrm{RT}_{2}$ (Table 3 ). The mean grain yield of wheat ( $\left.2131 \mathrm{~kg} \mathrm{ha}^{-1}\right)$ with $F_{3}$ was 11.6 and $2.1 \%$ higher than $F_{2}$ and $F_{1}$, respectively. Positive interaction was observed among tillage and nitrogen management and CT/RT $T_{2}+F_{3}$ recorded highest mean grain yield of wheat (2175 $\left.\mathrm{kg} \mathrm{ha}^{-1}\right)$ and was identical to yield (2170 $\left.\mathrm{kg} \mathrm{ha}^{-1}\right)$ observed under $\mathrm{CT}+\mathrm{F}_{2}$.

Minimized soil disturbance, creation of viable seedbed, supportive soil physical condition and less crop-weed competition at critical stages of crop growth through reduced tillage resulted in better expressions of growth and yield parameters significantly contributing towards higher maize yield under modified reduced tillage $\left(\mathrm{RT}_{2}\right)$ (Sheoran et al., 2009). Tolessa et al. (2014) also observed identical maize grain yield under minimum and CT in Ethiopia under rainfed conditions. Heavy flush of weeds (Commelina benghalensis, Trainthema portulacastrum, etc.) due to no herbicide application was the devastating factor for yield loss with $\mathrm{RT}_{1}$ in maize. When compared to $\mathrm{CT}, \mathrm{RT}_{1}$ resulted into higher weed density and dry weight of weeds in maize, while in wheat it recorded lower density and dry weight of weeds. However, when $\mathrm{RT}_{1}$ was integrated with chemical weed control $\left(R T_{2}\right)$, it drastically reduced the density and dry weight of weeds in both the crops. However, wheat growth was positively affected due to higher moisture conservation under $\mathrm{CT}$. More proliferation of roots leading to better extraction of moisture and nutrients under CT might be the possible reason for improving wheat yield 
Table 3 : Effect of tillage and nitrogen application on the grain yield ( $\mathrm{kg} \mathrm{ha}^{-1}$ ) of rainfed maize and wheat (2000-01 to 2011-12)

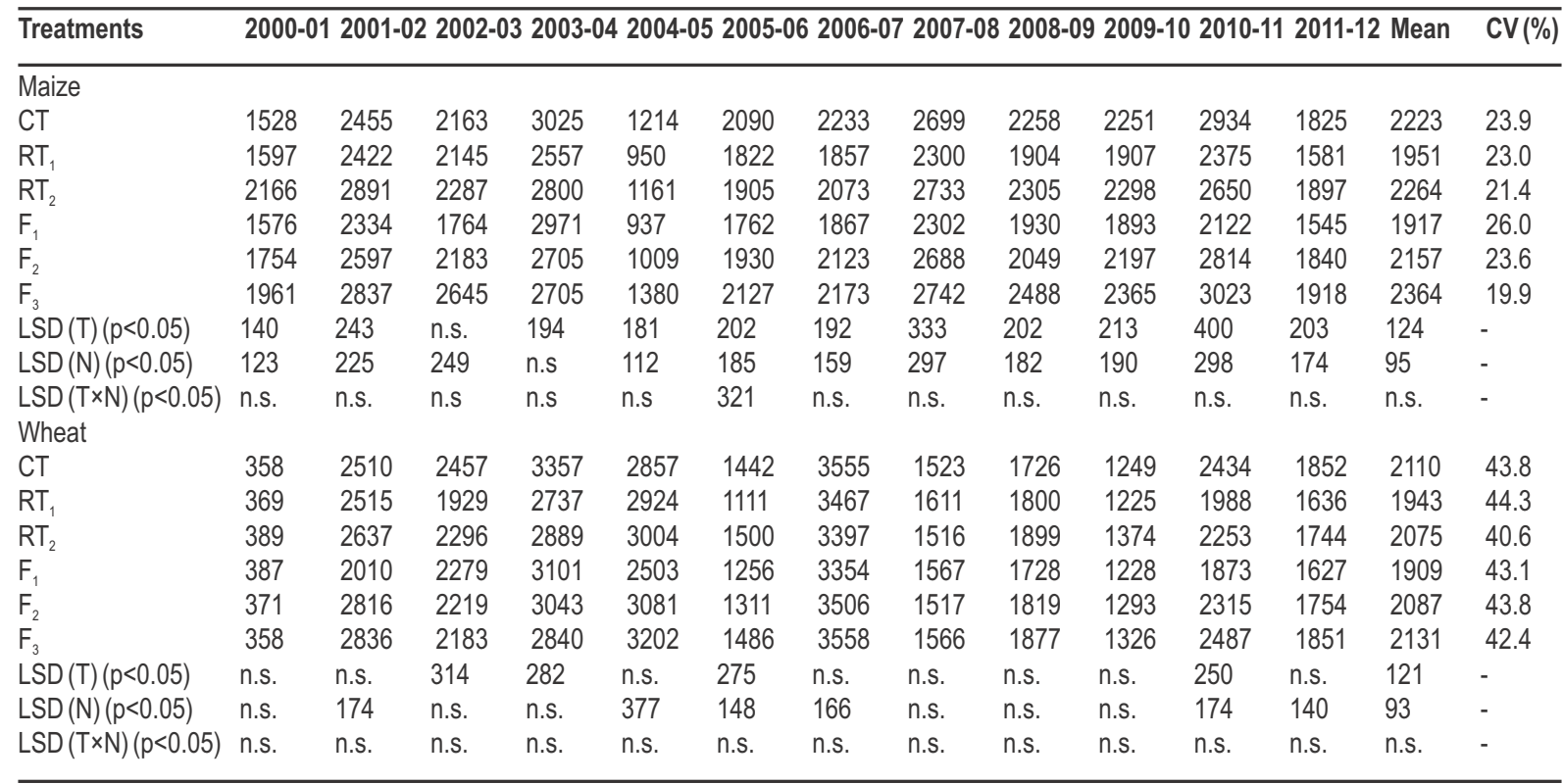

LSD : Least Significant Difference; T: Tillage; N: Nitrogen; n.s.: non-significant; CV: Coefficient of variation (\%); CT: Conventional tillage; RT1: Reduced tillage; RT2: Reduced tillage + herbicide; F1: $100 \% \mathrm{~N}$ from organic source, F2: $50 \% \mathrm{~N}$ from organic source $+50 \% \mathrm{~N}$ from inorganic source; $\mathrm{F} 3: 100 \% \mathrm{~N}$ from inorganic source

(Singh and Singh, 2008). The current findings are similar to Usman et al. (2012) and Mitra et al. (2014) who recorded similar wheat grain yields with reduced and conventional tillage.

Availability of sufficient moisture during monsoon season to maize crop ensured efficient utilisation of inorganic $\mathrm{N}$ fertiliser $\left(F_{3}\right)$ resulting in higher yield. The wheat crop in the region is generally sown on conserved moisture and poor soil moisture conditions coupled with low temperature which might have delayed the transformation of nutrients to available form through $F_{1}$ fertilisation and ultimately resulting in low yield. Improved crop yield in manured plots reinforced with inorganic nitrogen application could be attributed to the carryover effects of minerals for efficient utilisation of growth resources, thus maintaining stable yield performance and substantial improvement in soil health and associated indices (Lemcoff and Loomis, 1994).

The RWUE during the study period ranged from 1.76 to $7.08 \mathrm{~kg} \mathrm{ha}^{-1} \mathrm{~mm}^{-1}$ in maize and from 4.66 to $47.54 \mathrm{~kg} \mathrm{ha}^{-1} \mathrm{~mm}^{-1}$ in wheat (Table 4). The rain water use efficiency (RWUE) of maize and wheat was significantly influenced among tillage and $\mathrm{N}$ treatments during individual year and for the pooled data. Both $\mathrm{RT}_{2}$ and $\mathrm{CT}$ were statistically at par with each other but significantly superior to RT for mean RWUE in both the crops. Tillage treatments of $\mathrm{RT}_{2}$ and CT increased mean RWUE in maize by 13.3 and $12.9 \%$ over $R T_{1}$, respectively in maize and by 7.1 and $5.7 \%$ in wheat. Ghosh et al. (2015) also reported better moisture conservation under conservation tillage in maize-wheat cropping system. Better utilization of rainwater under $\mathrm{RT}_{2}$ and $\mathrm{F}_{3}$ reflected in terms of high yield resulted into high values of RWUE under these treatments due to interaction effect. Significantly higher mean RWUE $\left(4.55 \mathrm{~kg} \mathrm{ha}^{-1} \mathrm{~mm}^{-1}\right)$ in maize was recorded under $F_{3}$ than $F_{2}$ and $F_{1}$, while it was significantly superior to only $F_{1}$ in case of wheat. Dang et al. (2005) reported improved water use efficiency with nitrogen application in rainfed wheat-maize system.

The net returns in maize varied from US\$ $70.96 \mathrm{ha}^{-1}$ under $\mathrm{CTF}_{1}$ to US\$222.60 ha ${ }^{-1}$ under $\mathrm{RT}_{2} \mathrm{~F}_{3}$ (CV 43.0\%), while benefit-cost ratio $(\mathrm{B}: \mathrm{C})$ ranged from 1.15 under $\mathrm{RT}_{1} \mathrm{~F}_{1}$ to 1.88 under $\mathrm{RT}_{2} \mathrm{~F}_{3}$ (CV 16.4\%). Among tillage treatments, $\mathrm{RT}_{2}$ recorded the highest net returns (US\$160.24 ha ${ }^{-1}$ ) and $B: C$ ratio (1.59) in maize, while under nitrogen management treatments, $F_{3}$ recorded the highest net returns (US\$195.88 ha ${ }^{-1}$ ) and $\mathrm{B}: \mathrm{C}$ ratio (1.75).

In wheat, net returns of US\$ $189.50 \mathrm{ha}^{-1}$ obtained with $\mathrm{RT}_{1} \mathrm{~F}_{1}$ increased to US\$315.45 ha ${ }^{-1}$ under $\mathrm{RT}_{2} \mathrm{~F}_{3}$ (CV 17.9\%). The $\mathrm{B}: \mathrm{C}$ ratio in wheat ranged between 1.65 under $\mathrm{CTF}_{1}$ to 2.28 under $\mathrm{RT}_{2} \mathrm{~F}_{3}$ (CV 16.4\%). Wheat crop under tillage treatment $\mathrm{RT}_{2}$ recorded the highest NR (US\$268.98 ha-1) and B:C ratio (20.3) while among nitrogen management treatments, $F_{3}$ recorded the highest net returns (US\$303.81 ha ${ }^{-1}$ ) and $\mathrm{B}: \mathrm{C}$ ratio (2.21). The treatment combination $\mathrm{RT}_{2} \mathrm{~F}_{3}$ recorded the highest net returns and 
Table 4 : Effect of tillage and nitrogen application on the rain water use efficiency ( $\mathrm{kg} \mathrm{ha}^{1} \mathrm{~mm}^{1}$ ) of maize and wheat grown under rainfed conditions (2000-01 to 2011-12)

\begin{tabular}{|c|c|c|c|c|c|c|c|c|c|c|c|c|c|c|}
\hline Treatments & $2000-$ & $2001-0$ & $2002-0$ & $32003-0$ & $2004-0$ & $2005-0$ & $2006-0$ & $2007-0$ & $2008-0$ & 2009-1 & $2010-11$ & 2011-12 & Mean & CV (\%) \\
\hline \multicolumn{15}{|l|}{ Maize } \\
\hline CT & 1.76 & 3.98 & 3.77 & 5.95 & 2.44 & 5.12 & 4.49 & 6.96 & 3.83 & 5.76 & 5.41 & 2.46 & 4.33 & 36.7 \\
\hline $\mathrm{RT}_{1}$ & 1.84 & 3.92 & 3.74 & 5.03 & 1.91 & 4.47 & 3.74 & 5.94 & 3.23 & 4.88 & 4.38 & 2.13 & 3.77 & 34.5 \\
\hline $\mathrm{RT}_{2}$ & 2.49 & 4.68 & 3.99 & 5.51 & 2.34 & 4.67 & 4.17 & 7.05 & 3.91 & 5.88 & 4.89 & 2.56 & 4.35 & 32.9 \\
\hline$F_{1}$ & 1.81 & 3.78 & 3.07 & 5.84 & 1.89 & 4.32 & 3.76 & 5.94 & 3.28 & 4.85 & 3.92 & 2.08 & 3.71 & 37.6 \\
\hline $\mathrm{F}_{2}$ & 2.02 & 4.21 & 3.80 & 5.32 & 2.03 & 4.73 & 4.27 & 6.94 & 3.48 & 5.63 & 5.19 & 2.48 & 4.18 & 36.2 \\
\hline $\mathrm{F}_{3}$ & 2.25 & 4.59 & 4.61 & 5.32 & 2.78 & 5.21 & 4.37 & 7.08 & 4.22 & 6.05 & 5.58 & 2.59 & 4.55 & 31.9 \\
\hline LSD (T) $(p<0.05)$ & 0.16 & 0.39 & n.s. & 0.38 & 0.36 & 0.49 & 0.39 & 0.86 & 0.34 & 0.55 & 0.74 & 0.27 & 0.22 & - \\
\hline LSD $(N)(p<0.05)$ & 0.14 & 0.36 & 0.43 & n.s. & 0.23 & 0.45 & 0.32 & 0.77 & 0.31 & 0.49 & 0.55 & 0.23 & 0.19 & - \\
\hline $\begin{array}{l}\operatorname{LSD}(T \times N)(p<0.05) \\
\text { Wheat }\end{array}$ & n.s. & n.s. & n.s. & n.s. & n.s. & 0.79 & n.s. & n.s. & n.s & n.s. & n.s. & n.s. & n.s. & - \\
\hline $\mathrm{CT}$ & 4.66 & 37.07 & 21.76 & 24.22 & 15.95 & 14.96 & 12.62 & 20.87 & 33.91 & 43.21 & 12.71 & 17.67 & 21.63 & 52.2 \\
\hline $\mathrm{RT}_{1}$ & 4.82 & 37.15 & 17.09 & 19.75 & 16.33 & 11.52 & 12.31 & 22.07 & 35.36 & 42.37 & 10.38 & 15.61 & 20.40 & 57.8 \\
\hline $\mathrm{RT}_{2}$ & 5.07 & 38.94 & 20.34 & 20.84 & 16.77 & 15.56 & 12.06 & 20.77 & 37.30 & 47.54 & 11.76 & 16.64 & 21.97 & 57.7 \\
\hline$F_{1}$ & 5.05 & 29.69 & 20.19 & 22.37 & 13.97 & 13.02 & 11.91 & 21.46 & 33.96 & 42.50 & 9.78 & 15.53 & 19.95 & 54.5 \\
\hline $\mathrm{F}_{2}$ & 4.84 & 41.59 & 19.66 & 21.95 & 17.20 & 13.60 & 12.44 & 20.78 & 35.74 & 44.74 & 12.09 & 16.73 & 21.78 & 57.1 \\
\hline $\mathrm{F}_{3}$ & 4.66 & 41.89 & 19.34 & 20.49 & 17.88 & 15.42 & 12.63 & 21.45 & 36.87 & 45.88 & 12.99 & 17.67 & 22.26 & 56.6 \\
\hline LSD (T) $(p<0.05)$ & n.s. & n.s. & 2.78 & 2.03 & n.s. & 2.86 & n.s. & n.s. & n.s. & n.s. & 1.30 & n.s. & 1.22 & - \\
\hline $\operatorname{LSD}(N)(p<0.05)$ & n.s. & 2.57 & n.s. & n.s. & 2.10 & 1.53 & 0.59 & n.s. & n.s. & n.s. & 0.91 & 1.33 & 1.02 & - \\
\hline LSD $(T \times N)(p<0.05)$ & n.s. & n.s. & n.s. & n.s. & n.s. & n.s. & n.s. & n.s. & n.s. & n.s. & n.s. & n.s. & n.s. & - \\
\hline
\end{tabular}

LSD : Least Significant Difference; T: Tillage; N: Nitrogen; n.s.: non-significant; CV: Coefficient of variation (\%); CT: Conventional tillage; $\mathrm{RT}_{1}$ : Reduced tillage; $\mathrm{RT}_{2}$ : Reduced tillage + herbicide; $\mathrm{F}_{1}: 100 \% \mathrm{~N}$ from organic source; $\mathrm{F}_{2}: 50 \% \mathrm{~N}$ from organic source $+50 \% \mathrm{~N}$ from inorganic source; $\mathrm{F}_{3}: 100 \% \mathrm{~N}$ from inorganic source

benefit-cost ratio in both maize and wheat. Hashim et al. (2017) reported improved economic returns with the nitrogen management in maize-wheat system.

The mean reduction in cost of cultivation due to reduced tillage ( $\mathrm{RT}_{1}$ and $\mathrm{RT}_{2}$ ) over CT was 10.2 and $9.6 \%$ in maize and wheat, respectively and the treatment $\mathrm{RT}_{2} \mathrm{~F}_{3}$ proved most economical in terms of net returns and benefit-cost ratio in both crops. The average price of per kg nutrient supplied through organic fertilizer was higher (US\$ 0.4702) than the inorganic fertilizer (US\$ 0.2296). The comparatively lower cost of inorganic fertilizers than organic was responsible for higher net returns and benefit-cost ratio of all the treatment combinations involving inorganic fertilizers in both the crops. Mitra et al. (2014) also reported a higher $B$ : $C$ ratio in $R T$ against $C T$ in wheat despite lesser yield, which was mainly due to huge curtailment in the cost of land preparation under RT. Landers et al. (2001) have also recorded higher net income in no-tillage through reducing production cost by $15-20 \%$ compared with CT. Kelava et al. (2000) also achieved higher economic efficiency with nonconventional tillage systems than CT system.

The regression model in maize provided a non-significant yield predictability and higher prediction error for different treatments over years, while in wheat it gave significantly higher yield predictability and lower prediction error (Table 5). The rainfall received in June and July had a positive effect (non-significant) on yield produced in all treatments, except a negative effect in case of $\mathrm{RT}_{1} \mathrm{~F}_{3}$ in June and CTF $\mathrm{F}_{1}$ in July. However, rainfall in August had a significant negative effect on yield produced under $F_{1}$ in combination with all the three tillage treatments whereas it caused inconspicuous effect on the remaining treatments. September rainfall also favourably though non-significantly influenced the yield with $F_{1}$ and $F_{2}$ sources of nitrogen but caused a non-significant negative effect with $\mathrm{F}_{1}$ in combination with all the three tillage treatments.

In wheat, the rainfall received in October and November had a non-significant negative effect on yield obtained under all the treatments, except positive effect in $\mathrm{RT}_{1} \mathrm{~F}_{3}$ in November. Also December rainfall had a negative effect on yield of all treatments but the effect was significant only in $\mathrm{CTF}_{1}, \mathrm{CTF}_{2}, \mathrm{RT}_{1} \mathrm{~F}_{1}$ and $\mathrm{RT}_{2} \mathrm{~F}_{1}$. The rainfall received in January and February had a significant positive effect on yield produced by all treatments, except in $R T_{1} F_{2}, R_{1} F_{3}$ and $R T_{2} F_{3}$ in January. However, rainfall received in March caused a non-significant negative effect on yield under all treatments of tillage and nitrogen sources.

The sustainability yield index (SYI) was highest $(60.7 \%)$ in maize under $\mathrm{RT}_{2} \mathrm{~F}_{3}$ and in wheat $(51.5 \%)$ with $\mathrm{CTF}_{2}$. The results showed a large variation in the SYI values of tillage and nitrogen treatments in both crops owing to variation in crop seasonal rainfall, besides erratic distribution of monthly rainfall received during June to September in maize and October to April in wheat 
Table 5: Effect of monthly rainfall on grain yield of maize and wheat under different tillage and nitrogen application treatments (2000 to 2012)

\begin{tabular}{|c|c|c|c|c|}
\hline Treatment & Regression model & $\mathbf{R}^{2}$ & Error & SYI \\
\hline \multicolumn{5}{|l|}{$\overline{\text { Maize }}$} \\
\hline $\mathrm{CTF}_{1}$ & $Y=3348^{* *}+2.50$ (Jun) $-0.14($ Jul $)-5.26^{*}$ (Aug) -2.37 (Sep) & 0.52 & 521.7 & 0.430 \\
\hline $\mathrm{CTF}_{2}$ & $Y=2930^{* *}+0.73($ Jun $)+0.32($ Jul $)-3.71$ (Aug) $+0.89($ Sep $)$ & 0.52 & 469.1 & 0.526 \\
\hline $\mathrm{CTF}_{3}$ & $Y=2743^{* *}+1.01$ (Jun) $+0.68($ Jul) -3.38 (Aug) $+1.63($ Sep $)$ & 0.50 & 487.4 & 0.552 \\
\hline $\mathrm{RT}_{1} \mathrm{~F}_{1}$ & $Y=2433^{* *}+1.96$ (Jun) +0.61 (Jul) $-3.60^{*}$ (Aug) -1.57 (Sep) & 0.52 & 390.4 & 0.383 \\
\hline $\mathrm{RT}_{1} \mathrm{~F}_{2}$ & $Y=2054^{*}+0.88$ (Jun) $+1.35($ Jul $)-2.91$ (Aug) $+1.46($ Sep $)$ & 0.49 & 463.1 & 0.427 \\
\hline $\mathrm{RT}_{1} \mathrm{~F}_{3}$ & $Y=2303^{* *}-0.01($ Jun $)+0.73(\mathrm{Jul})-2.48($ Aug $)+2.82($ Sep) & 0.62 & 367.4 & 0.536 \\
\hline $\mathrm{RT}_{2} \mathrm{~F}_{1}$ & $Y=2456^{* *}+2.61($ Jun $)+1.37$ (Jul) $-3.69^{*}($ Aug $)-1.03$ (Sep) & 0.57 & 408.6 & 0.473 \\
\hline $\mathrm{RT}_{2} \mathrm{~F}_{2}$ & $Y=2231^{*}+1.05($ Jun $)+1.75($ Jul $)-2.66$ (Aug) $+1.28($ Sep $)$ & 0.48 & 466.6 & 0.521 \\
\hline $\begin{array}{l}\mathrm{RT}_{2} \mathrm{~F}_{3} \\
\text { Wheat }\end{array}$ & $Y=2372^{* *}+1.26$ (Jun) +1.64 (Jul) -2.54 (Aug) $+1.73($ Sep) & 0.56 & 403.2 & 0.607 \\
\hline $\mathrm{CTF}_{1}$ & $Y=1079^{* *}-3.57$ (Oct) -14.41 (Nov) $-21.54^{*}(\mathrm{Dec})+21.08^{* *}(\mathrm{Jan})+25.79^{* \star}(\mathrm{Feb})-3.52(\mathrm{Mar})$ & $0.95^{\star *}$ & 309.7 & 0.487 \\
\hline $\mathrm{CTF}_{2}$ & $Y=1335^{\star *}-2.72(\mathrm{Oct})-46.48(\mathrm{Nov})-24.07^{*}(\mathrm{Dec})+18.71^{* *}(\mathrm{Jan})+31.08^{\star *}(\mathrm{Feb})-6.85(\mathrm{Mar})$ & $0.93^{*}$ & 399.3 & 0.515 \\
\hline $\mathrm{CTF}_{3}{ }_{3}^{2}$ & $Y=1349^{*}-3.12(\mathrm{Oct})-41.06(\mathrm{Nov})-20.65(\mathrm{Dec})+18.58^{*}(\mathrm{Jan})+28.43^{* *}(\mathrm{Feb})-5.64(\mathrm{Mar})$ & $0.87^{*}$ & 498.8 & 0.487 \\
\hline $\mathrm{RT}_{1} \mathrm{~F}_{1}$ & $Y=1169^{\star}-1.87(\mathrm{Oct})-16.85(\mathrm{Nov})-23.75^{*}(\mathrm{Dec})+13.68^{*}(\mathrm{Jan})+23.17^{\star *}(\mathrm{Feb})-2.80(\mathrm{Mar})$ & $0.88^{*}$ & 406.7 & 0.407 \\
\hline $\mathrm{RT}_{1} \mathrm{~F}_{2}$ & $Y=1281^{*}-0.95(\mathrm{Oct})-18.61(\mathrm{Nov})-22.78(\mathrm{Dec})+14.19(\mathrm{Jan})+25.01^{*}(\mathrm{Feb})-4.97(\mathrm{Mar})$ & 0.74 & 696.7 & 0.372 \\
\hline $\mathrm{RT}_{1} \mathrm{~F}_{3}$ & $Y=1375^{*}+0.21(\mathrm{Oct})-32.95(\mathrm{Nov})-20.48(\mathrm{Dec})+11.87(\mathrm{Jan})+25.57^{*}(\mathrm{Feb})-5.46(\mathrm{Mar})$ & 0.80 & 608.2 & 0.417 \\
\hline $\mathrm{RT}_{2} \mathrm{~F}_{1}$ & $Y=1258^{* *}-2.54(\mathrm{Oct})-21.81(\mathrm{Nov})-24.41^{* *}(\mathrm{Dec})+16.49^{* *}(\mathrm{Jan})+24.32^{* *}(\mathrm{Feb})-4.21(\mathrm{Mar})$ & $0.95^{\star *}$ & 278.4 & 0.482 \\
\hline $\mathrm{RT}_{2} \mathrm{~F}_{2}$ & $Y=1499^{* *}-1.09(\mathrm{Oct})-43.26(\mathrm{Nov})-24.18(\mathrm{Dec})+14.50^{*}(\mathrm{Jan})+26.30^{*}(\mathrm{Feb})-6.88(\mathrm{Mar})$ & $0.85^{*}$ & 507.5 & 0.467 \\
\hline $\mathrm{RT}_{2} \mathrm{~F}_{3}$ & $Y=1575^{\star \star}-0.11(\mathrm{Oct})-42.68(\mathrm{Nov})-23.92(\mathrm{Dec})+11.52(\mathrm{Jan})+25.94^{*}($ Feb $)-4.93(\mathrm{Mar})$ & 0.83 & 542.6 & 0.474 \\
\hline
\end{tabular}

${ }^{*},{ }^{* *}$ significant at $p<0.05$ and $p<0.01$, respectively; $\mathrm{R}^{2}$ : Coefficient of determination; SYI: Sustainability yield index; CT: Conventional tillage; $\mathrm{RT}_{1}$ : Reduced tillage; $\mathrm{RT}_{2}$ : Reduced tillage + herbicide; $\mathrm{F}_{1}: 100 \% \mathrm{~N}$ from organic source; $\mathrm{F}_{2}: 50 \% \mathrm{~N}$ from organic source $+50 \% \mathrm{~N}$ from inorganic source; $\mathrm{F}_{3}: 100 \% \mathrm{~N}$ from inorganic source

in each year. Among tillage practices, $\mathrm{RT}_{2}$ was superior in maize while CT was superior in wheat. Among nitrogen sources, $\mathrm{F}_{3}$ was superior in both crops. Thus, $\mathrm{RT}_{2}$ together with $\mathrm{F}_{3}$ showed its longterm superiority for attaining maximum productivity, profitability and RWUE in maize, as well as wheat crop and it was closely followed by $\mathrm{CTF}_{3}$. Sheoran et al. (2009) reported higher SYI under minimum tillage and nitrogen management.

Rainfall events in June, July and September played a vital role in increasing maize yields under sub-humid conditions. Rainfall in June coincided with preparatory tillage and consequently led to moisture conservation in the soil profile. Spatio-temporal distribution of rainfall in July is the determining factor for timely sowing of maize crop ensuring improved germination and desired crop stand. The anticipated adverse effect of August rainfall could be ascribed to water stagnation owing to occasional high rainfall events $(2001,2002,2004,2006$, 2008 and 2011) as maize crop is highly sensitive to excess moisture conditions. The positive impact of rains in September could be attributed to the moisture availability during reproductive (cob formation, tasseling, silking, pollination and grain formation) stages of the crop, which is the most significant phase in the ontogeny of maize plant (completed in a time span of 15-20 days), and shortage of water at this stage causes a drastic reduction in cob yield (Rashid and Rasul, 2012). It was observed that rainwater stored in the soil profile during September supplied soil moisture to the crop upto physiological maturity.
Rains are normally received in the region during January and February months of the winter season which proved vital for growth and yield improvement in wheat. The temperature during December and January remains low resulting in negligible evapotranspiration losses and whatever little precipitation was received during this period was efficiently utilised by the growing plants. Any rainfall received in February is quite useful as the wheat plant passes through booting, flowering and heading stages, and thus requires adequate moisture to sustain growth. The water stress at anthesis may reduce pollination resulting in higher pollen sterility, shrivelled grains and reduction in test weight and reduced crop yields (Ashraf, 1998). Recharging of soil profile with rains in February assured crop moisture needs upto mid March. In March, temperature starts rising; however, wheat reaches maturity during this month and water demand is reduced (Singh et al., 2005; Deo et al., 2017).

The present study demonstrates that $\mathrm{RT}_{2}$ in combination with $\mathrm{F}_{3}$ resulted in higher grain yield, RWUE, net profit and $\mathrm{B}: \mathrm{C}$ ratio of maize and wheat compared to other treatments. Similar superior performance of reduced tillage + herbicide and/or CT over reduced tillage has been previously reported (Sheoran et al., 2009; Akbarnia et al., 2010; Rusu et al., 2013). Singh et al. (2011) also reported significantly higher productivity of both maize and wheat with CT than minimum tillage under rainfed sub-humid conditions of north-western Himalayas. Most of the rainfed soils in the region are low in fertility, especially nitrogen and the response and performance of inorganic fertilisers remain superior than 
organic sources in the short run due to fast release and availability of the nutrients. Probably, for this reason, application of nitrogen through $\mathrm{F}_{3}$ proved to be superior to other sources. These results coincide with those of Díaz-Zorita et al. (2002) who reported in a review that maize yields increased more by nitrogen fertilisation than by tillage application under sub-humid and semi-arid regions of Argentina.

It is likely that the short-term nitrogen locking in reduced tillage systems compared with conventional tillage systems did not prevail for long-term, as indicated by yield levels in different treatments in the present study. Fertiliser nitrogen management can be greatly influenced by changes in tillage. Soils in the present study have a loamy texture with more than $1 \mathrm{~m}$ depth, and consequently have fair water retention capacity to support crop growth under rainfed conditions. Similar to $C T$ and $R T_{1}$, the $R T_{2}$ was also able to capture enough rainwater during pre- and postmonsoon rains to replenish the soil profile, but it was better in controlling weeds through herbicide application, thus, supporting good crop growth and performing better in combination with inorganic nitrogen $\left(F_{3}\right)$. Ghosh et al. (2017) has also reported the beneficial effect of nitrogen application on maize crop.

The study shows promising possibilities for energy and labour saving due to the utilisation of non-conventional soil tillage systems and would help farmers in Shivalik foothills of northern India to curtail production expenses with the shift of conventional tillage to reduced/conservation tillage practices.

\section{Acknowledgments}

The authors sincerely thank the All India Coordinated Research Project for Dryland Agriculture, Indian Council of Agricultural Research - Central Research Institute for Dryland Agriculture, Hyderabad, India for providing financial assistance.

\section{References}

Akbarnia, A., R. Alimardani and S. Baharloeyan: Performance comparison of three tillage systems in wheat farms. Aus. J. Crop Sci., 4, 586-589 (2010).

Ashraf, M.Y.: Yield and yield components response of wheat (Triticum aestivum L.) genotypes tinder different soil water deficit conditions. ActaAgrono. Hung., 46, 45-51 (1998).

Bhatt, R., K.L. Khera and S. Arora: Effect of tillage and mulching on yield of corn in submontaneous rainfed region of Punjab, India. Int. J. Agric. Bio., 6, 126-128 (2004).

Cruse, R.M. and T.S. Colvin: Effect of different tillage systems on energy conservation. Progress Report, Integrated Farm Management Demonstration Program. lowa State University, Ames, IA(1989).

Dang, T.H., G.X. Cai, S.L. Guo, M.D. Hao and L.K. Heng: Effect of nitrogen management on yield and water use efficiency of rainfed wheat and maize in northwest China. Pedosphere, 16, 495-504 (2006).

Deo, K., S.R. Mishra, A.K. Singh, A.N. Mishra and A. Singh: Water requirement of wheat crop for optimum production using
CROPWAT model. J. Med. Plants Stud., 5, 338-342 (2017).

Díaz-Zorita, M., G.A. Duarte and J.H. Grove: A review of no-till systems and soil management for sustainable crop production in the subhumid and semiarid Pampas of Argentina. Soil Tillage Res., 65, 1-18 (2002).

Draper, N.R. and H. Smith:Applied Regression Analysis John Wiley, New York (1998).

Ghosh, A.P., A. Dass, P. Krishnan. R. Kaur and K.S. Rana:Assessment of photosynthetically active radiation, photosynthetic rate, biomass and yield of two maize varieties under varied planting dates and nitrogen application. J. Environ. Biol., 38, 683-688 (2017).

Ghosh, B.N., P. Dogra, N.K. Sharma, R. Bhattacharyya and P.K. Mishra: Conservation agriculture impact for soil conservation in maizewheat cropping system in the Indian sub-Himalayas. Int. Soil Water Conserv. Res., 3, 112-118 (2015).

Gomez, K.A. and A.A. Gomez: Statistical Procedures for Agricultural Research. John Wiley, New York (1984).

Hashim, M., S. Dhar, A.K. Vyas and C.B. Singh: Yield trends and changes in physico-chemical properties of soil in maize-wheat cropping system under integrated nutrient management. J. Environ. Biol., 38, 727-734 (2017).

Hussain, I., K.R. Olson and S.A. Ebelhar: Impacts of tillage and no-till on production of maize and soybean on an eroded Illinois silt loam soil. Soil Tillage Res., 52, 37-49 (1999).

Kelava, I., B. Stipesevic, M. Josipovic and I. Zugec: Investigation of reduced soil tillage for some arable crops in eastern Croatia, Possibilities of rational soil tillage for Winter wheat (Triticum aestivum) in Baranja region, 15th ISTRO Conference, Fort Worth, USA(2000).

Lal, R.: Soil carbon sequestration to mitigate climate change. Geoderma, $123,1-22(2004)$

Landers, J.N., H.M. Saturnino and P.L. de Freitas: Organizational and policy consideration in zero tillage. In: The Environment and Zero Tillage (Eds.: H.M. Saturnino and J.N. Landers), Rome: FAO pp. 13-24 (2001).

Lemcoff, J.H. and R.S. Loomis: Nitrogen and density influences on silk emergence, endosperm development and grain yield in maize (Zea mays L.). Field Crops Res., 38, 63-72 (1994).

Maruthi Sankar, G.R., P.K. Mishra, K.L. Sharma, S.P. Singh, A.K. Nema, D.K. Kathmale, S.K. Upadhye, M.S. Sidhpuria, M. Osmman, G. Ravindera Chary, J. Kusuma Grace, B. Venkateshwarlu and A.K. Singh: Efficient tillage and nutrient practices for sustainable pearl millet productivity in different soil and agro-climatic conditions. Exp. Agri., 48, 1-20 (2012).

Maruthi Sankar, G.R., K.L. Sharma, G.N. Dhanapal, M.A. Shankar, P.K. Mishra, B. Venkateshwarlu and J. Kusuma Grace: Influence of soil and fertiliser nutrients on sustainability of rainfed finger millet yield and soil fertility in semi-arid Alfisols. Commun Soil Sci. Plant Anal., 42, 1462-1483 (2010)

Mitra, B., S. Mookherjee and S. Das: Performances of wheat (Triticum aestivum) under various tillage and nitrogen management in subHimalayan plains of West Bengal. J Wheat Res., 6, 150-153 (2014).

Nema, A.K., G.R. Maruthi Sankar and S.P.S. Chauhan: Selection of superior tillage and fertiliser practices based on rainfall and soil moisture effects on pearl millet yield under semi-arid Inceptisol. J. Irrig. Drain. E-ASCE, 134, 361-371 (2008).

Rashid, K. and G. Rasul: Rainfall Variability and Maize Production over the Potohar Plateau of Pakistan. Pakistan J. Meteorology, 8, 63-74 
(2012).

Rusu, T., I. Bogdan, P. Moraru, A. Pop, I. Oroian, D. Marin, O. Ranta, S. Stanila, M. Gheres, M. Duda and C. Mogosan: Influence of minimum tillage systems on the control of Convolvulus arvensis $\mathrm{L}$. on wheat, maize and soybean. J. Food Agric. Environ., 11, 563$566(2013)$

Sharma, K.L., J. Kusuma Grace, U.K. Mandal, N. Pravin Gajbhiye, K. Srinivas, G.R. Korwar, V. Ramesh, K. Ramachandran and S.K. Yadav: 2008. Evaluation of long-term soil management practices using key indicators and soil quality indices in a semi-arid tropical Alfisol. Aust. J. Soil Res., 46, 368-377 (2008).

Sharma, K.L., U.K. Mandal, K. Srinivas, K.P.R. Vittal, B. Mandal, J. Kusuma Grace and V. Ramesh: Long term soil management effects on crop yields and soil quality in dryland Alfisols. Soil Tillage Res., 83, 246-259 (2005).

Sharma, P., G.R. Maruthi Sankar and V. Abrol: Statistical assessment of tillage and nitrogen management for sustainable soil moisture and productivity of maize and wheat in dry sub-humid inceptisoils. Indian J. Soil Conserv., 39, 212-219(2011).

Sharma, S., G.R. Maruthi Sankar, C.H. Thakurand and R.A. Sharma: Modelling of soybean yield for sustainability based on rainfall and soil and plant relationships under semi-arid Vertisols in central India. Agropedol., 19, 121-134 (2009).

Shaver, T.M., G.A. Peterson, L.R. Ahuja, D.G. Westfall, L.A. Sherrod and G. Dunn: Surface soil physical properties after twelve years of dryland no till management. Soil Sci. Soc. America J., 66, 1296-1303 (2002).

Sheoran, P., V. Sardana, S. Singh, B. Bhushan, S.S. Bawa and C.B.
Singh: Long-term effect of tillage and nitrogen sources on the sustainability and productivity of maize (Zea mays)-wheat (Triticum aestivum) cropping system under rainfed conditions. Indian J. Agric. Sci., 79, 259-263 (2009).

Singh, R., A.R. Sharma, S.K. Dhyani and R.K. Dube: Tillage and mulching effects on performance of maize (Zea mays)-wheat (Triticum aestivum) cropping system under varying land slopes. Indian J. Agric. Sci., 81, 330-335 (2011).

Singh, S., S. Singh, S.S. Bawa, S.C. Sharma and A. Salaria: Impact of Makowal type water system on crop productivity in Shivalik foothills of India. J. Environ. Biol., 36, 969-977 (2015).

Singh, S., P. Sheoran, A.S. Dhindwal and M.S. Bhattoo: Influence of irrigation levels on productivity, water use and crop coefficient of late-sown wheat (Triticum aestivum). Environ. Ecology, 23, 801. $805(2005)$.

Singh, V.P. and V.K. Singh: Effect of tillage practices ad seed rates on the performance of large seeded lentil. J. Food Legumes, 21, 49-50 (2008).

SPSS: 2007. SPSS Base 16.0 User's Guide. SPSS Inc., Chicago (2007). Sundermeier, A.P. and K.R. Islam, Y. Raut, R.C. Reeder and W.A. Dick: Not-ill impacts of soil biophysical carbon sequestration. Soil Sci. Soc. America J., 75, 1779-1788 (2011).

Tolessa, D., C.C. Du Preez and G.M. Ceronio: Effect of tillage system and nitrogen fertilisation on organic matter content of Nitisols in Western Ethiopia. African J. Agric. Res., 9, 3171-3184 (2014).

Usman, K., S.K. Khalil and D. Ghulam: Tillage and N Impact on Wheat Production and NEfficiency under Rice-Wheat Cropping System in North-western Pakistan. PhillipAgricult. Scient., 95, 33-42 (2012). 